\title{
Lobster Population Parameter in Bumbang Bay, Central Lombok

\author{
Parameter Populasi Lobster Perairan Teluk Bumbang, Lombok Tengah
}

\author{
Yonvitner $^{1,7}$, Zulhamsyah Imran ${ }^{2,8}$, Sulaeman Martasuganda ${ }^{3}$, Beni Osta Nababan ${ }^{4}$, Fransiskus Mao Tokan ${ }^{5}$, Septian \\ Dwi Cahyo ${ }^{6}$, Rifki Aldi Ramadhani ${ }^{7}$
}

${ }^{1}$ Department of Aquatic Resources Management, Faculty of Fisheries and Marine Sciences. IPB University. Indonesia

${ }^{2}$ Department of Aquatic Resources Management, Faculty of Fisheries and Marine Sciences. IPB University. Indonesia

${ }^{3}$ Department of Fish Harvesting Technology and Management, Faculty of Fisheries and Marine Sciences. IPB University. Indonesia

${ }^{4}$ Department of Natural Resources and Environment Economy, Faculty of Economy and Management. IPB University. Indonesia

${ }^{5}$ Coastal and Marine Management Major, Graduate School IPB. Indonesia

${ }^{6}$ Researcher in Coastal and Marine Study Center, PPM Institution. IPB University. Indonesia

${ }^{7}$ Researcher in Disaster Study Center, PPM Institution. IPB University. Indonesia

${ }^{8}$ Deputy Director of SEAMEO Tropical Biology-Bogor. Indonesia

\section{ARTICLE INFO}

Received: Juny 10, 2019

Accepted: October 20, 2019

*) Corresponding author:

E-mail: yonvitr@yahoo.com

\section{Keywords:}

lobster, Bumbang bay, population structure, management, sustainable

\section{Kata Kunci:}

lobster, teluk Bumbang, struktur populasi, pengelolaan, berkelanju$\tan$

\begin{abstract}
Bumbang bay is one of the lobster fishing areas in Central Lombok District, where fishing is carried out at all times and has the potential to disrupt the sustainability of the population in the future. Data is collected from the stock of lobster stocks that are still in fishing cages. Potential risks and fishing pressure could be assessed through length and weight, growth, structure size and potential recruitment analysis. The results of the study found 6 species of lobsters, of which are 2 dominant species were pearl lobster (45.5\%) and sand lobster $(44.5 \%)$ of the total catch. The Length and weight relationship have a negative allometric pattern which is (pearls lobster $\mathrm{b}=2.04$ and sand lobster $=1.2$ ). The growth rate is relatively slow with a growth rate coefficient of 0.2-0.49 per year. Therefore, recruitment per biomass from the population is also low and exploitation rate about 0.6 . The population growth and recruitment relatively low and increasing the exploitation rate, potential to unsustainable of the lobster population in the future.
\end{abstract}

\section{Abstrak}

Perairan Teluk Bumbang adalah salah satu pusat perikanan lobster di Lombok Tengah, dimana penangkapan dilakukan setiap waktu dan berpotensi mengganggu keberlanjutan populasi dimasa yang akan datang. Potensi risiko dan tekanan penangkapan dapat dikaji melalui analisis panjang dan bobot, pertumbuhan, struktur ukuran dan potensi recruitment. Hasil penelitian ditemukan sebanyak 6 jenis lobster, dimana 2 jenis dominan yaitu lobster mutiara $(45,5 \%)$ dan lobter pasir $44,5 \%$ dari total tangkapan. Hubungan panjang dan berat memiliki pola allometrik negatif (lobster mutiara $b=2,04$ dan lobster pasir $=1,2$ ). Pertumbuhan tergolong lambat dengan koefisien laju pertumbuhan 0,2-0,49 per tahun. Begitu juga recruitment per biomass dari populasi juga rendah dan eksploitasi tergolong tinggi yaitu 0,6 . Kemampuan tumbuh yang lambat dengan recruitment yang rendah serta eksploitasi tinggi, potensial menganggu keberlanjutan populasi lobster dimasa yang akan datang.

Cite this as: Yonvitner, Zulhamsyah, I., Sulaeman, M., Beni, O. N., Fransiskus, M. T., Septian, D. C., \& Rifki, A. R. (2019). Lobster Population Parameter in Bumbang Bay, Central Lombok. Jurnal Ilmiah Perikanan dan Kelautan, 11(2):40-50. http://doi. org/10.20473/jipk.v11i2.13185 


\section{Introduction}

Bumbang Bay is one of the lobster producers in Lombok Island. There are 500 fishermen in total including the nursery fishermen, merchant, and 300 heads of the family of catch fishermen. This condition shows a high amount of fishing activity and demands the need to control these activities to prevent overexploitation. To ensure the fishing stays sustainable, there needs to be an indicator of how many are left for reserve and how many are available for fishing.

The population parameters related to stock that have been found are catch composition, size structure, growth, exploitation rate, and recruitment capability. Other than fishing, another factor affecting the stock is competition, e.g. against another species such as green crab (Goldstein et al., 2017) where 33\% of all lobsters with carapace size larger than $80 \mathrm{~mm}$ are preyed upon by said green crabs.

The growth rates of spiny lobsters are $11.2 \pm 0.32$ $\mathrm{mm}$ per month for its length and $1.81 \pm 0.19$ grams to $2.28 \pm 0.21 \mathrm{grams} /$ month (Syafrizal et al., 2018). Species Panulirus elephans also have a relatively slow growth rate of $1.9 \mathrm{~mm}$ a year whether in the wild are in a marine protected area (MPA). Moreover, it has been recorded that the maximum asymptotic length for female lobsters is $116 \mathrm{~mm}$ and $185 \mathrm{~mm}$ for male lobsters. Meanwhile, the mortality rate (naturally occurring) inside the MPA is 0.41 a year, while outside the MPA is 0.78 a year. Furthermore, the mortality rate by fishing is 0.43 from the total population (Bevacqua et al., 2010).

Lobster growth is also determined by density, food availability, extreme environment changes, and also depth. The lobster variant called southern rock lobster in Tasmania is proven to grow slowly in deep waters. Lobster species Jasus edwardsii reached $110 \mathrm{~mm}$ of asymptotic carapace length for its male and $105 \mathrm{~cm}$ for its female (Chandrapavan et al., 2010). From both examples above, it seems that lobster growths generally are relatively slow.

Tropical lobster management is highly dependent on temperature indicator, food, and competition between aquatic biota, so to sustain stock availability and mitigate overfishing, there needs to be a proper scoring of population indicator. Another important note on lobster management aside from population parameters, there are also thresholds of size, growth, and mortality, and also yield per recruitment potency to ensure sustainability.

Researches about variant availability, size structure of lobster population catches, growth rate, and yield per recruit capability need to be done, therefore relevant information could be obtained and serves as stock sustain- ability parameter. Next, protection of the fishing area is crucial in keeping mortality rate in check, because naturally occurring mortality is already high. Policies needed to ensure all things mentioned above are concerning the environment condition, population status, size, and intensity of external pressure to ensure the management of lobster aquaculture stays optimal in the future.

\section{Material and Method}

\subsection{Research Time and Location}

The research was done at Bumbang Bay, Middle Lombok in June 2017. The research location includes lobster larvae catching area at Bumbang Bay and also its fishermen as shown on the map below (Figure 1).

\subsection{Data Collection Procedure}

Data are collected from all lobster catching and collecting sites. Because of the lobster catching prohibition, data are collected from the stock obtained by fishermen's lobster traps. All the variants and apparent sizes are observed to obtain needed data. Data obtained are total carapace length (mm), lobster weight (grams), aquatic environment conditions, and much other documentation. No samples were sorting as the sample itself was limited.

\subsection{Data Analysis}

Data obtained among the research sites are lobster variants caught by fishermen, dimensional data such as length, and weight, catching area and sites, prices, and other interview data relevant to business system done by fishermen.

Analysis done within the research are length analysis to determine growth, length, and weight correlation, and lobster recruitment. Data analyses were done using a descriptive statistical approach; determining the mean and standard of deviation (Wallpole, 1993). Lengthweight correlation analysis was done using a cubic law approach; $\mathrm{W}=\mathrm{aL}^{\mathrm{b}}$, where $\mathrm{W}$ is the fish mass in grams, $\mathrm{L}$ is the total length in mm, and $a$ and $b$ serve as constant acquired through regression.

Group distribution and determination are done using separate normal distribution approach. The normal distribution obtained presents an age group. Steps taken were: 1) Acquired carapace length data were grouped into classes based on length to determine lobster distribution frequency. 2) Frequency distribution data was analyzed with Battacharya's method of size separation principle. 3) Next, the normal distribution count was analyzed to find the population structure (age class). Normal curve approach principle was determined by the following function: $\ln \left(\mathrm{N}_{\mathrm{i}+1}\right)-\ln \left(\mathrm{N}_{\mathrm{i}}\right)=\mathrm{a}_{\mathrm{j}}+\mathrm{b}_{\mathrm{j}} \cdot \mathrm{L}_{\mathrm{i}}$, where 


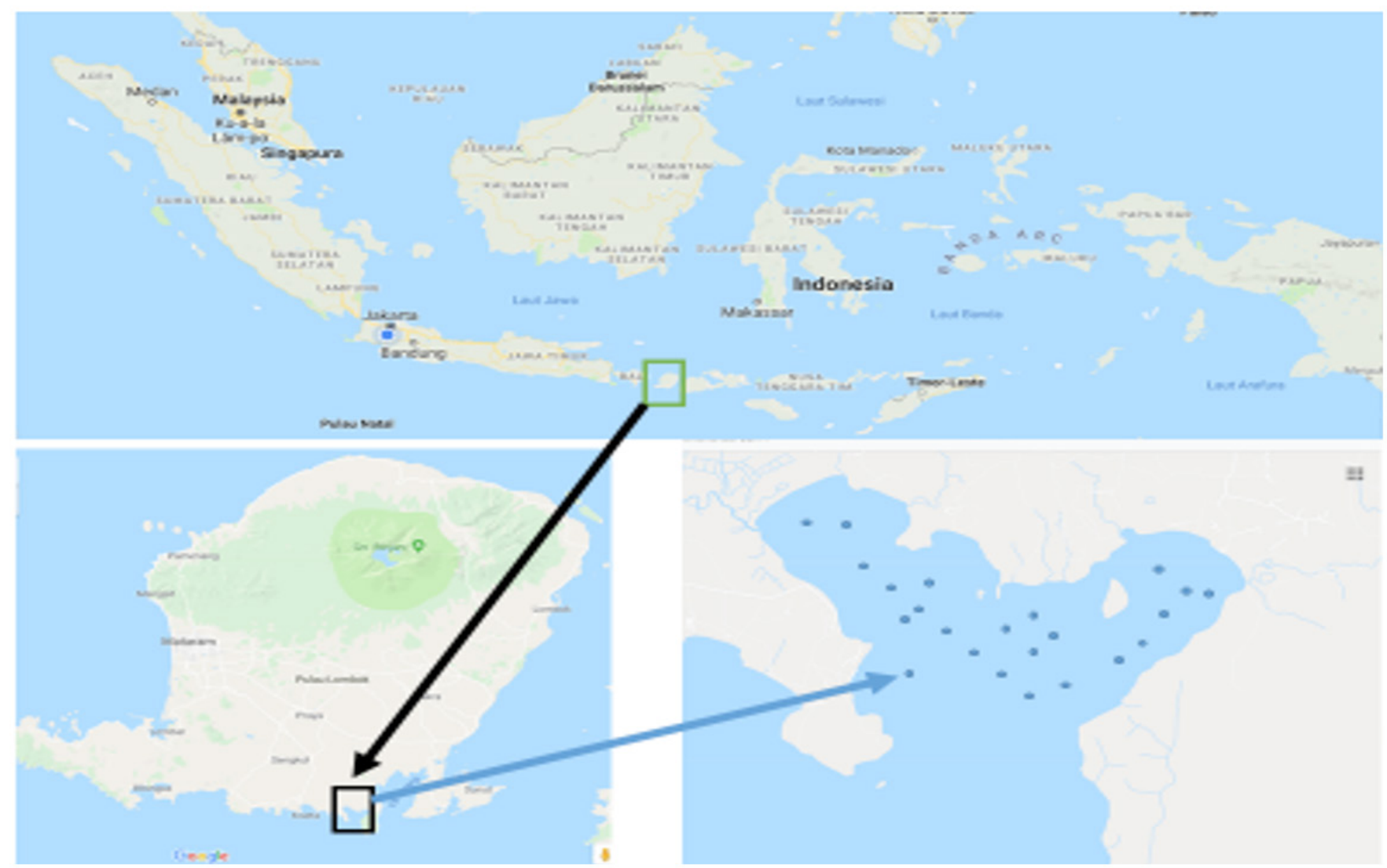

Figure 1. Lobster Research Site Bumbang Bay, Central Lombok

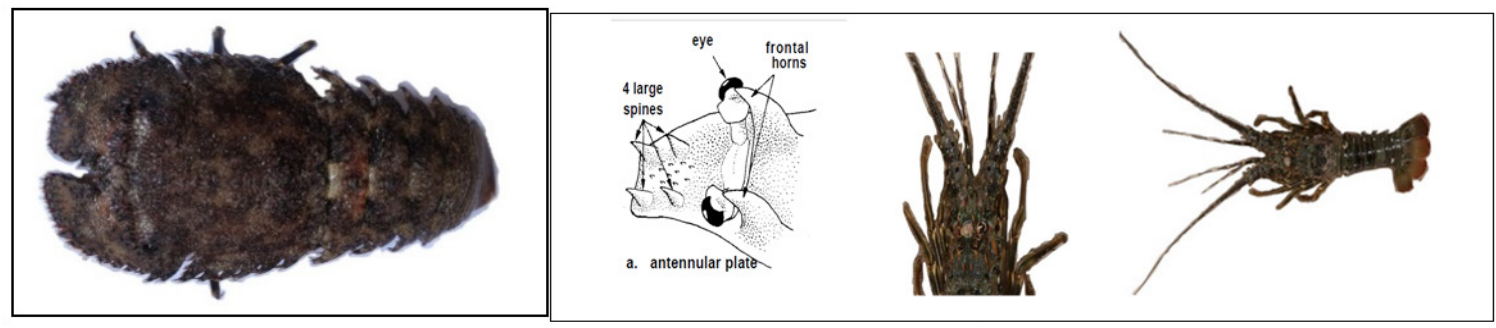

a
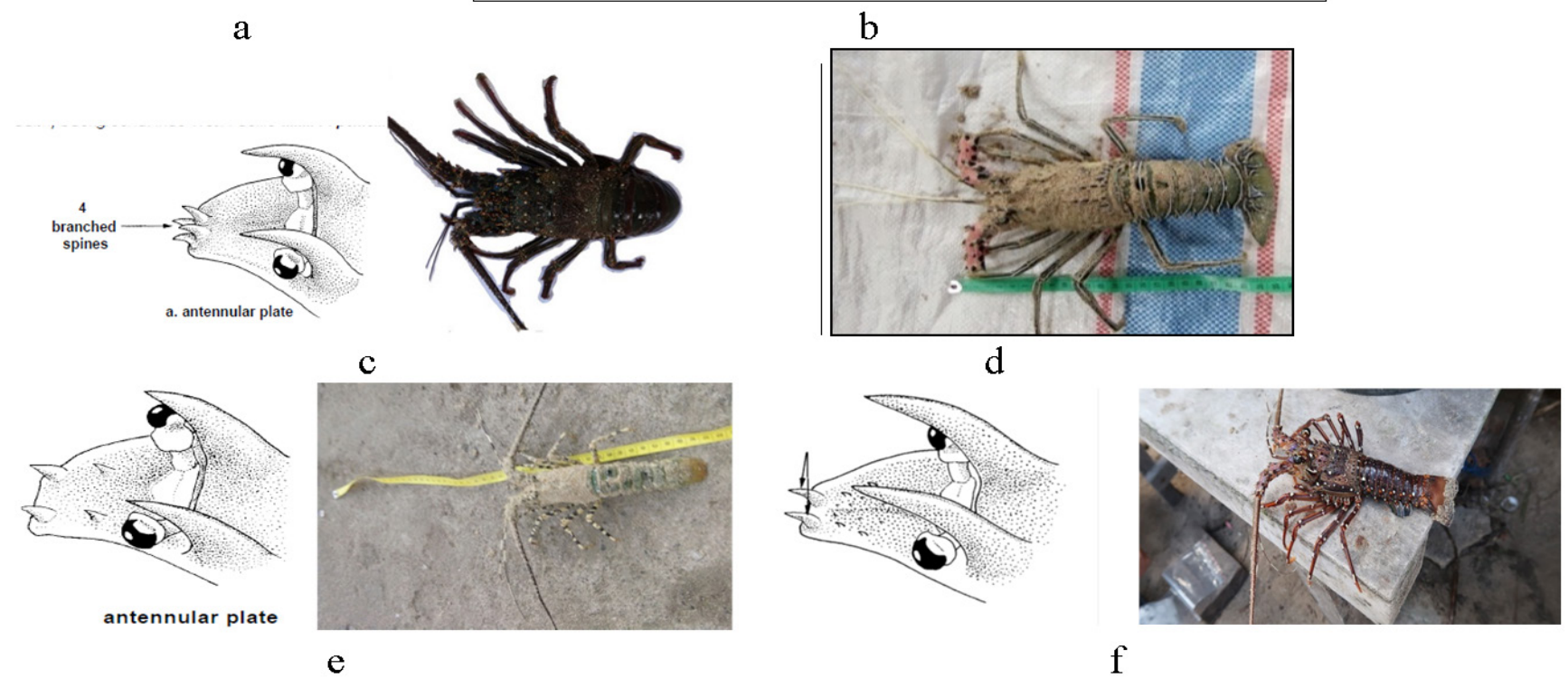

Figure 2. Slipper Lobster (Parrabicus antarticus) a; Spiny Lobster (Panulirus homarus) b; Pronghorn spiny Lobster (Panulirus penicillatus) c; Rock Lobster Panulirus versicolor d; Ornate spiny Lobster Panulirus ornatus e; Western Rock lobster Panulirus longipes longipes f. 
$\mathrm{N}_{\mathrm{i}}$ and $\mathrm{N}_{\mathrm{i}+1}$ are the same sequential components from lobster groups from the sample (e.g., member of $j$ age group) and $\mathrm{L}_{\mathrm{i}}$ is the upper limit of the class $\mathrm{N}_{\mathrm{i}}$. From here, the mean of normal distribution is $\mathbf{L} \mathbf{j}=\mathbf{- a j} / \mathbf{b j}$ and the standard of deviation is $(\mathbf{j})=\left(-\Delta \mathbf{L} / \mathbf{b}_{\mathrm{i}}\right)^{1 / 2}$, where $\Delta \mathrm{L}$ is a constant from the age group, then the index of separation (SI) is calculated with $\mathbf{S I}=\mathbf{A L} \mathbf{j} /(-\Delta \mathbf{L})$. Growth analysis was done using Sheperd's approach, which is: $\mathbf{S}=\left(\mathbf{s}_{\mathbf{A}}{ }^{2}+\mathbf{s}_{\mathbf{B}}{ }^{2}\right)^{1 / 2}$, where $S_{A}$ and $S_{B}$ are goodness-of-fit scores (Stz) acquired from Von Bartalanfy Growth Plot (VBGF) analysis of time $\left(\mathrm{t}_{\mathrm{z}}\right)$ from 0 to 0.25 .

\section{Results and Discussion}

\subsection{Lobster Variant at Bumbang Bay}

There are 6 species of lobster variants at Bumbang Bay. Those caught lobsters were dominated by lobsters from Palinuridae family, Panulirus genus, which includes 5 species, and one variant from the family Scyllaridae and Parribacus genus. Local names of these lobsters are fan lobster, sand lobster, bamboo lobster, stone lobster, batik lobster, and pearl lobster. The description of found variants is as follows.

\subsection{Catch Composition}

The composition is commonly related to adaptation and species conservation. Species with great adaptability, whether in exploitation zone or no-take zone (NTZ), usually shows high availability. From 6 recorded variants, 312 lobsters were obtained. Catch composition consists of $44.5 \%$ sand lobster, $45.5 \%$ pearl lobster, and the other 4 variants. Both of these variants are the main catch in Bumbang Bay. Catch composition is shown as follows in Figure 3.

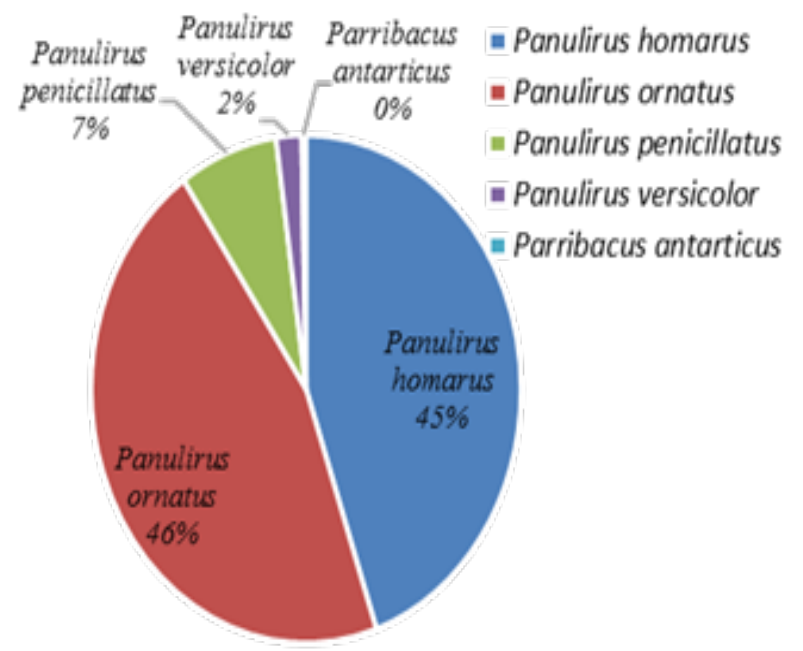

Figure 3. Lobster Catch Composition
Lobster population composition and amount serve as a population indicator in an ecosystem. Lobsters in no-take zones (NTZ) in a conservation area will be abundant (Buglass, 2018). However, an abundance of the population isn't without risk, because it serves as prey to predators such as reef fishes and other carnivorous fish. A higher composition of one variant than the other may be caused by a different dominant fishing technique on certain variants (Driscoll et al., 2015). So the amount of population, other than because of fishing, must be observed simultaneously with other competing or associating species.

\subsection{Weight-Length Correlation}

According to the result of length and weight calculation, it was found that the growth pattern of sand lobster and pearl lobster caught in Bumbang Bay are negative allometric, meaning that it grows in length quicker than it is in weight (Figure 4). Meanwhile, the analysis of the other variants was not performed.

T-test result came up as $95 \%$ true from value b towards value 3 for both lobsters, it was also acquired that $>t_{\text {tabel }}$ and shows negative allometric. Value $b$ shows low value because of ecological and biological factors (Manik, 2009). Ecological factors include weather, water quality, temperature, $\mathrm{pH}$, salinity, geographic position, and sampling technique (Zargar et al., 2012; Jenning et al., 2001). Biological factor includes gonad development, feeding habit, growth phase, and gender (Froese, 2006; Tarkan et al., 2006).

\subsection{Size Structure}

For the smallest sand lobster obtained was 18.22 $\mathrm{mm}$ (carapace length) and the longest was $101.88 \mathrm{~mm}$ (carapace length). Meanwhile, the smallest pearl lobster obtained was $11.55 \mathrm{~mm}$ (carapace length) and the longest was $101.92 \mathrm{~mm}$ (carapace length). Lobsters from both variants were taken each day and the mode obtained for sand lobster was $55.72 \mathrm{~mm}$ (carapace length) with total caught 22 lobsters, and for pearl lobster mode $60.55 \mathrm{~mm}$ with total caught 38 lobsters.

From all lobsters recorded, the longest was P. penicilatus with $260 . \mathrm{mm}$ with mean $177.4 \pm 5.77 \mathrm{~mm}$. While variant with the shortest length (smallest) recorded was Parribacus antarcticus with $110.3 \mathrm{~mm}$, other results are as follows (Table 1).

The length-frequency distribution of both lobsters is shown in Figure 5. According to Figure 5, it is known that length-frequency distribution for sand lobster ranges from $18.22 \mathrm{~mm}-101.88 \mathrm{~mm}$, with the highest class interval frequency on interval $54.22-57.22 \mathrm{~mm}$. Length frequency distribution of sand lobster ranges from 11.55 to $101.92 \mathrm{~mm}$, with the highest class interval frequency on interval $56.55-64.55 \mathrm{~mm}$. Length frequency distribution and group size distribution are shown in Figure 5. 
Table 1. Caught Lobster Length Range

\begin{tabular}{llcccc}
\hline Lobster Variant & Local Name & N & \multicolumn{3}{c}{ Total Length (mm) } \\
\cline { 3 - 6 } & & max & min & Mean \pm sd \\
\hline Panulirus homarus & Sand Lobster & 139 & 197,1 & 32,3 & $113,0 \pm 4,02$ \\
\hline Panulirus ornatus & Pearl Lobster & 142 & 202,6 & 53,2 & $144,1 \pm 2,84$ \\
\hline Panulirus penicillatus & Stone Lobster & 23 & 260,6 & 53,6 & $177,4 \pm 5,77$ \\
\hline Panulirus versicolor & Bamboo Lobster & 6 & 196,9 & 36,9 & $171,2 \pm 3,69$ \\
\hline Parribacus antarticus & Fan Lobster & 1 & 110,3 & - & - \\
\hline
\end{tabular}

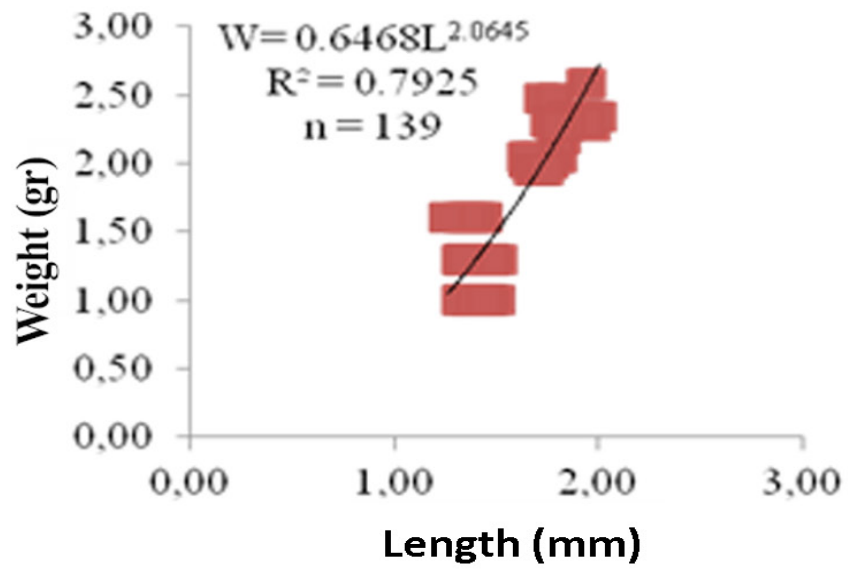

a

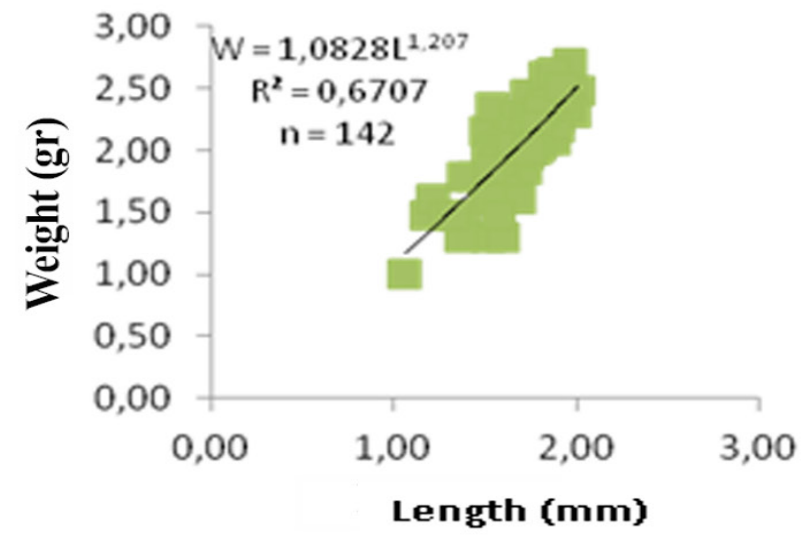

b

Figure 4. Length and Weight Relation of Spiny lobster and Ornate Spiny Lobster
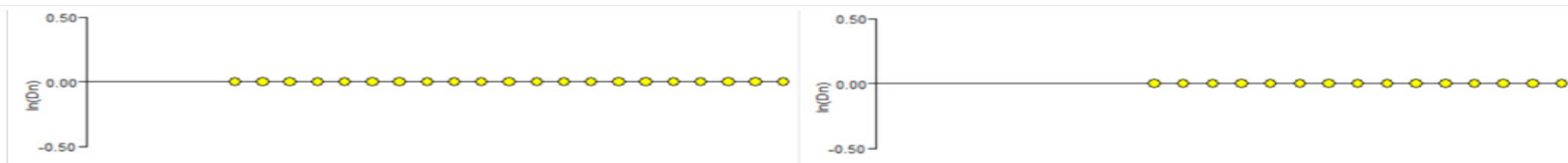

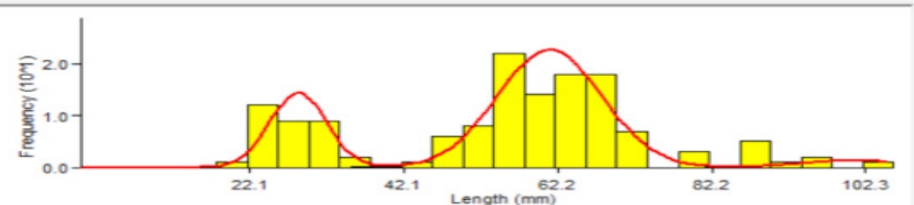

2.
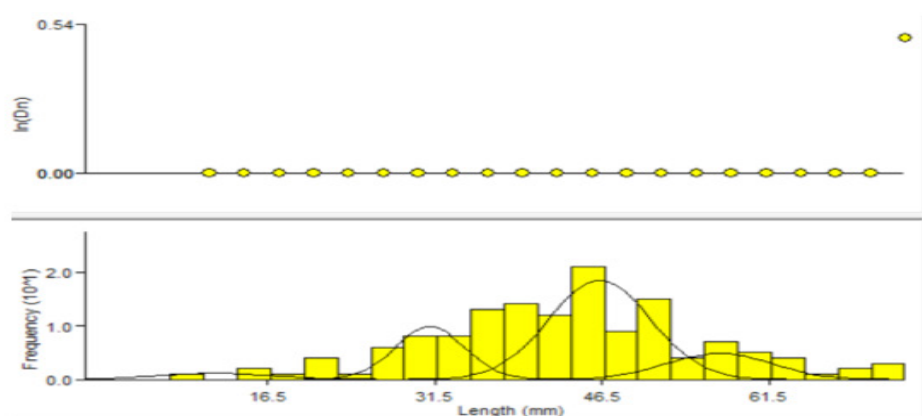

C.

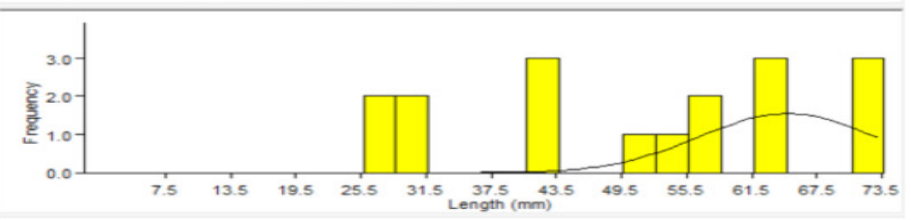

b

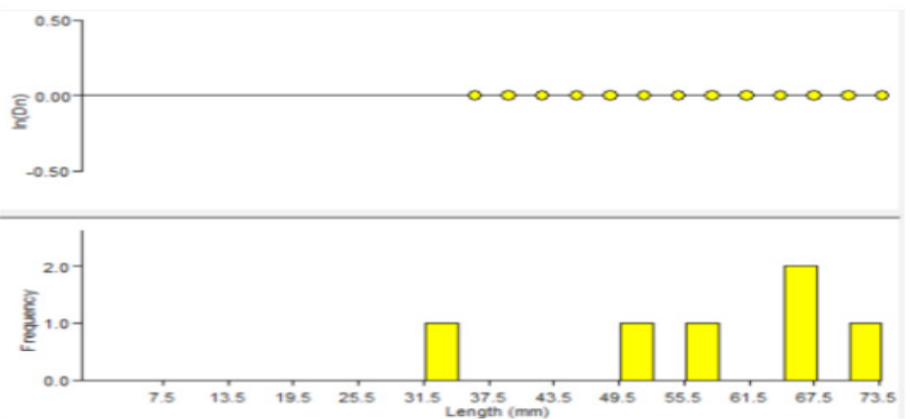

d

Figure 5. Length Frequency Distribution (a) Spiny Lobster (P. homarus) and (b) Pronghorn Spiny Lobster (P. penicillatus) c) Ornate Spiny Lobster (P. ornatus) and Rock Lobster (P. versicolor) 
Generally, size varies for each lobster variant caught. Sand lobster has three size groups, stone lobster has one size group, pearl lobster has four size groups, bamboo lobster one size group, and so does fan lobster. The biggest catch result from each variant varies from 46.30$61.09 \mathrm{~mm}$ with a total population reaching $39.54 \%$ from the total population. These data show that lobster sizes are distributed to different classes. Distributed means of size groups observed from the whole population are as follows (Table 2).
Caught sand lobsters have a relatively small size and dominantly sized below $17 \mathrm{~cm}$. This size period indicates that this lobster has a slow growth rate $(\mathrm{k}=0.14$ / year) and with breeding frequency twice a year or more, it means with said frequency and high fecundity it is presumed that the stock will suffice for 7 times (of harvesting) a year (Alborés, 2019). Growth could also be faster if food is sufficient because a more mature population tend to be opportunistic in their feeding habit (Blamey et al., 2018) and warmer temperature supports longevity (Harrington et al., 2019).

Table 2. Distribution of population size groups

\begin{tabular}{lcccc}
\hline Lobster Variant & Mean(mm) & Deviation(mm) & Population & Separation Index \\
\hline Sand Lobster & 28,33 & 3,710 & 33,48 & $\mathrm{n}, \mathrm{a}$ \\
& 61,09 & 6,860 & 97,03 & 3,380 \\
& 100,59 & 6,810 & 5,77 & 2,760 \\
\hline Stone Lobster & 64,72 & 8,060 & 10,4 & $\mathrm{Na}$ \\
\hline Pearl Lobster & 11,72 & 5,100 & 4,83 & $\mathrm{Na}$ \\
& 31,03 & 3,120 & 25,59 & 3,320 \\
& 46,30 & 4,580 & 70,51 & 2,440 \\
& 57,02 & 4,670 & 18,91 & 2,060 \\
\hline Bamboo Lobster & 71,75 & 18,515 & 6 & $\mathrm{n}, \mathrm{a}$ \\
\hline Fan Lobster & 110,3 & - & - & $\mathrm{Na}$ \\
\hline
\end{tabular}

The generic lobster variant has an average growth rate and slower on growing infinite length $(\mathrm{L} \infty)$. According to Table 3, sand lobster and pearl lobster have the same relative growth rate, while the fan lobster was slower. According to Saputra et al., (2008), the average size of caught lobsters or the size of the first catch are ideally not less than half of infinite length $(\mathrm{L} \infty)$. Homarus americouldus variant falls under one of the faster lobsters in developing their gonad fertility, affected by warm temperature (Bris et al., 2016). This correlation may as well serve as an indicator that there is a correlation between climate change to the gonad fertility scale of a fish.The result of the length analysis could be acquired from the carapace length. Gardner et al., (2015) states that the highest recruitment occurs at a size range between 60 to $64 \mathrm{~mm}$ for stone lobster. The catch chance is $50 \%$ of the total population $\left(\mathrm{Lc}_{50}\right.$ or $\left.\mathrm{Lc}\right)$. Lc could be used as first caught lobster average size indicator.
Obtained data of first catch size (Lc) of lobster in Bumbang Bay are $57.05 \mathrm{~mm}$ for sand lobster and 58.25 $\mathrm{mm}$ for pearl lobster. According to mode size (55.72 $\mathrm{mm})$ and Lc before, lobster size caught in Bumbang Bay waters are categorized as small, and so it could be hypothesized that the reproduction chance couldn't be guaranteed to suffice, and from utilization aspect it is categorized as overexploitation (growth overfishing) because it was dominated by smaller lobster. This condition may also indicate recruitment overfishing because the chance for reproduction is getting thinner. The same result was also found in research in Kebumen waters conducted by Saputra (2008), where Lc acquired was $56 \mathrm{~mm}$ while the $\mathrm{Lc}_{50}$ is $67 \mathrm{~mm}$, indicating a catch size less than ideal.

Catch chance will increase as length also increases, reaching maximum or close to the maximum from all 
catch size. The analysis result shows that the cumulative catch chance will increase with size greater than $70 \mathrm{~mm}$. Meaning the larger the size, the easier it is to catch, whether it's caused by maturity or a change in yield potency change. The presumptions of changes in catch chance are as follows (Figure. 7).

Yield per recruit potency or biomass per recruit or substantially high. At maximum exploitation rate, maximum yield potency decreases, as well as biomass per
Table 3. Lobster and its growth rate

\begin{tabular}{|l|l|l|l|}
\hline Lobster Variant & $\mathbf{k}$ & $\mathbf{L} \infty \mathbf{( m m})$ & To \\
\hline Sand Lobster & 0,42 & 110,75 & $-0,00035$ \\
\hline Stone Lobster & 0,45 & 137,07 & $-0,00206$ \\
\hline Pearl Lobster & 0,42 & 107,6 & $-0,00062$ \\
\hline Bamboo Lobster & 0,49 & 98,126 & $-0,00060$ \\
\hline Fan Lobster & 0,24 & 68,65 & $-0,00060$ \\
\hline
\end{tabular}

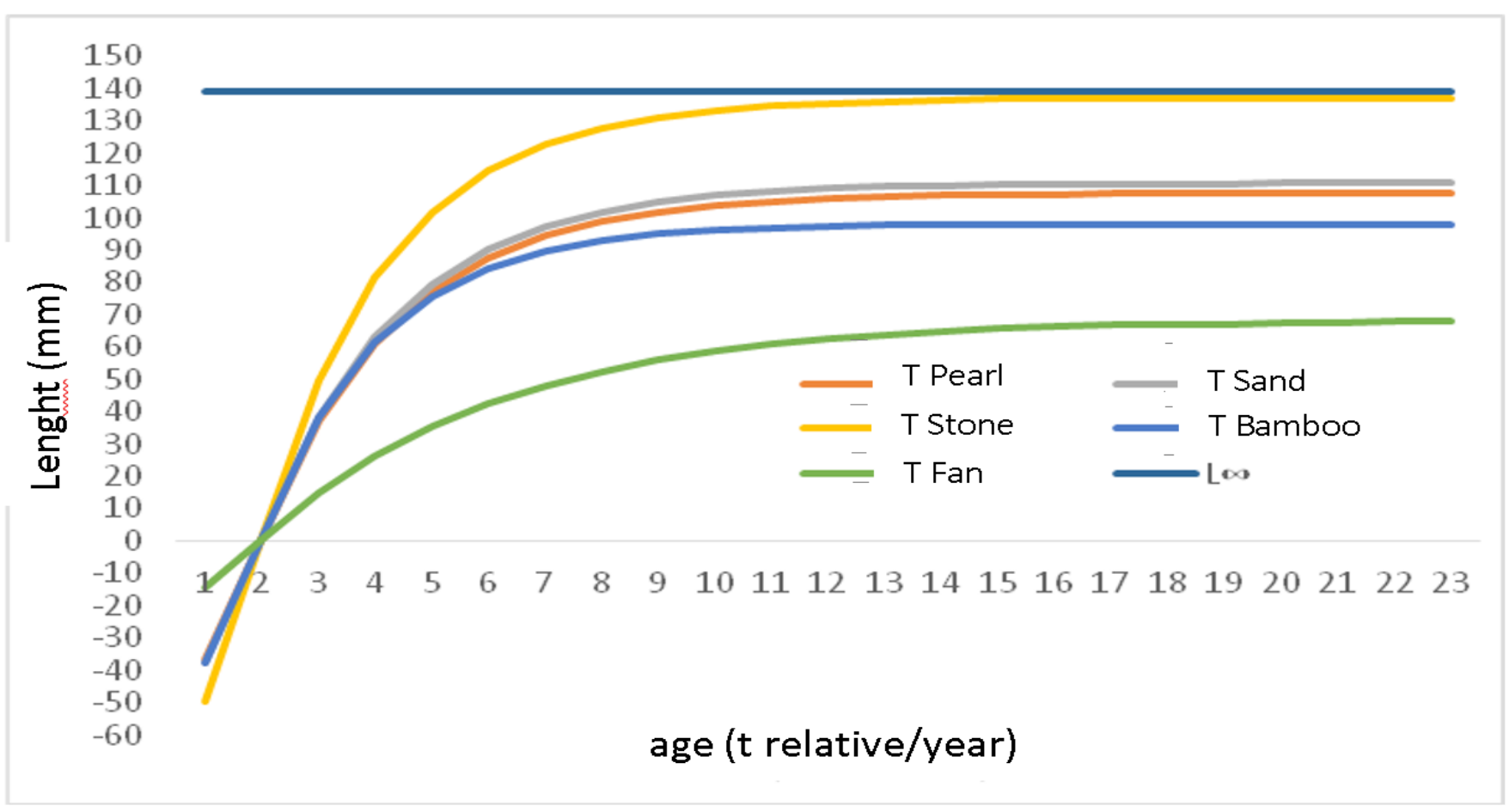

Figure 6. Growth rate and development of Lobsters

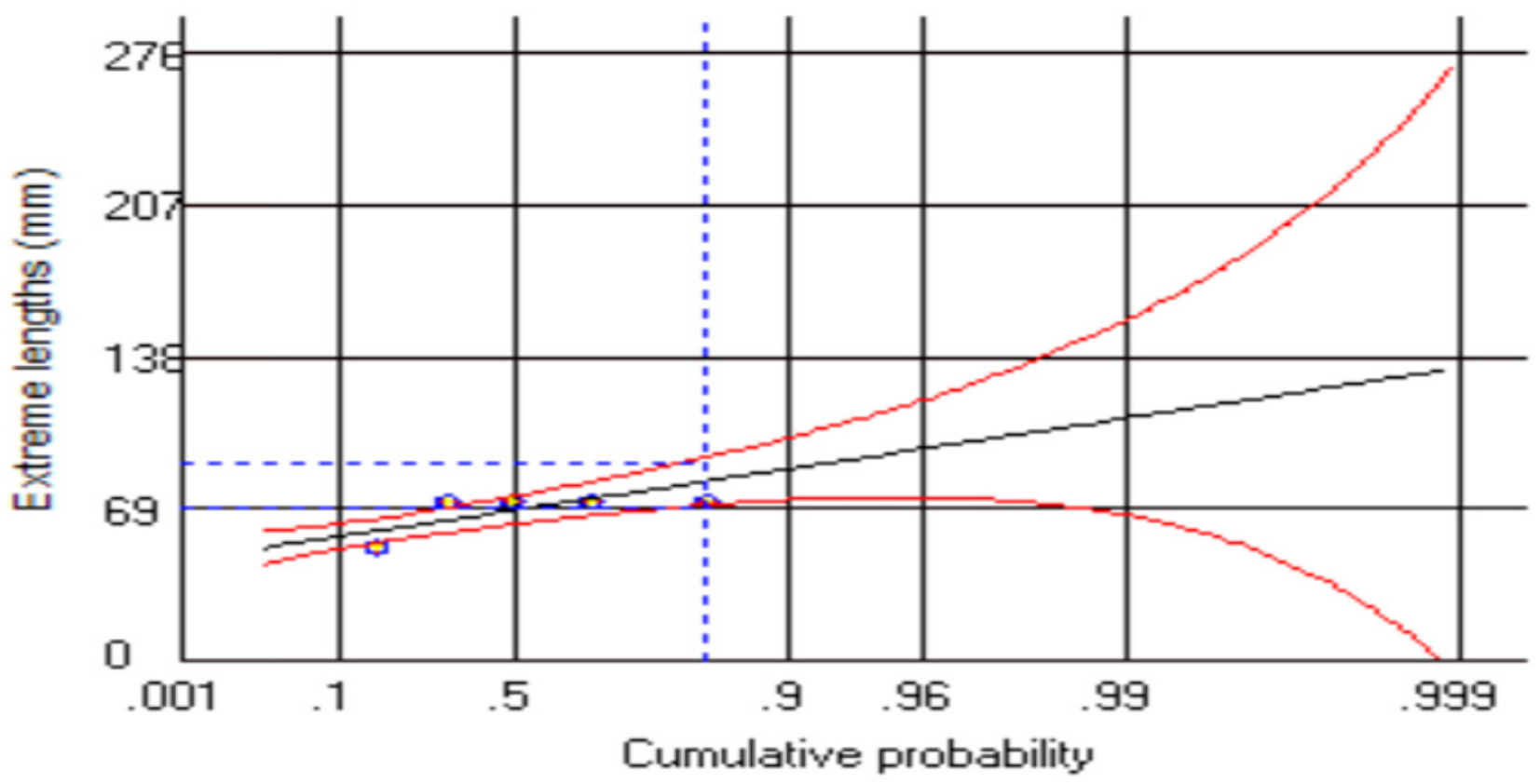

Figure 7. Cumulative Probability Catch of Total Lobster 
recruit. From Figure 8, it is shown that with an estimated ratio of catch size against infinity length reaching $109.12 \mathrm{~mm}$, the ratio of yield per recruit is less than $50 \%$ as well as biomass per recruit. It could be seen that there is a vulnerable phase of a lobster, if there were no fishing, the population will still decline as naturally occurring mortality still persists. The translocation process of catch size is necessary to improve the quality of catch size.

Lobster fishing in actual conditions that result in a smaller size than the length infinity $\left(\mathrm{L}_{\infty}\right)$ is defined as overfishing, so are mature gonad size that is larger than the average catch size. The high frequency of juveniles caught may incur three things, 1) high population of juveniles in the water, 2) Indiscriminate fishing tool (as in small mesh size, etc.), and 3) declining population of mature fish. Optimal management design would be the development of aquaculture and nursery, management and regulation of fishing tool size to catch juvenile fishes.

The amount and size of a new population in the waters are related to the ability in recruiting stock. Biomass recruit and catch stock potential are crucial as a base in determining catch allocation to keep lobster exploitation as sustainable (Caputi et al., 2018). The recruitment process shows larvae and juvenile attachment to the surface pattern to be relevant with catch size as the behavior of the population tends to group up in early days (Priyambodo et al., 2016).
The available stock should be utilized when it's still in its juvenile state to be prepared for when it's a mature stock. Because it will undergo an increase in mortality rate caused by predation, competition, or natural mortality.

Average lobster size caught in Walis Sand State Beach, Rye, with standard fishing equipment is $61.98 \pm 0.61 \mathrm{~mm}$. Fishing without a separation pouch on the equipment yields an average of $62.38 \pm 0.12 \mathrm{~mm}$ and the average size of lobster caught with scuba gear is $48.06 \pm 0.90 \mathrm{~mm}$ measured from its carapace (Clark et al., 2015). The amount of catch is highly dependent on lobster density (Clark et al., 2015). Goldstein et al., (2017) found that the lobster distribution in Great Bay Estuary is higher than areas further from the estuary, although there is an abundance of another Crustacea such as crabs in the estuary.

The average size of lobster is used as an indicator in developing harvest strategy (Klaer et al., 2012). In many practices of lobster processing, it is known that the complexity and connectivity between social systems and lobster habitat as an ecological system are inseparable (Partelow and Boda, 2015).

Lobsters in conservation sites tend to be different than the ones outside conservation sites, in regards to its mortality rate. Panulirus elephas has a mortality rate of 0.41 per year in situ and 0.78 ex-situ, including natural causes and catching (Bevacqua et al., 2010). Other than
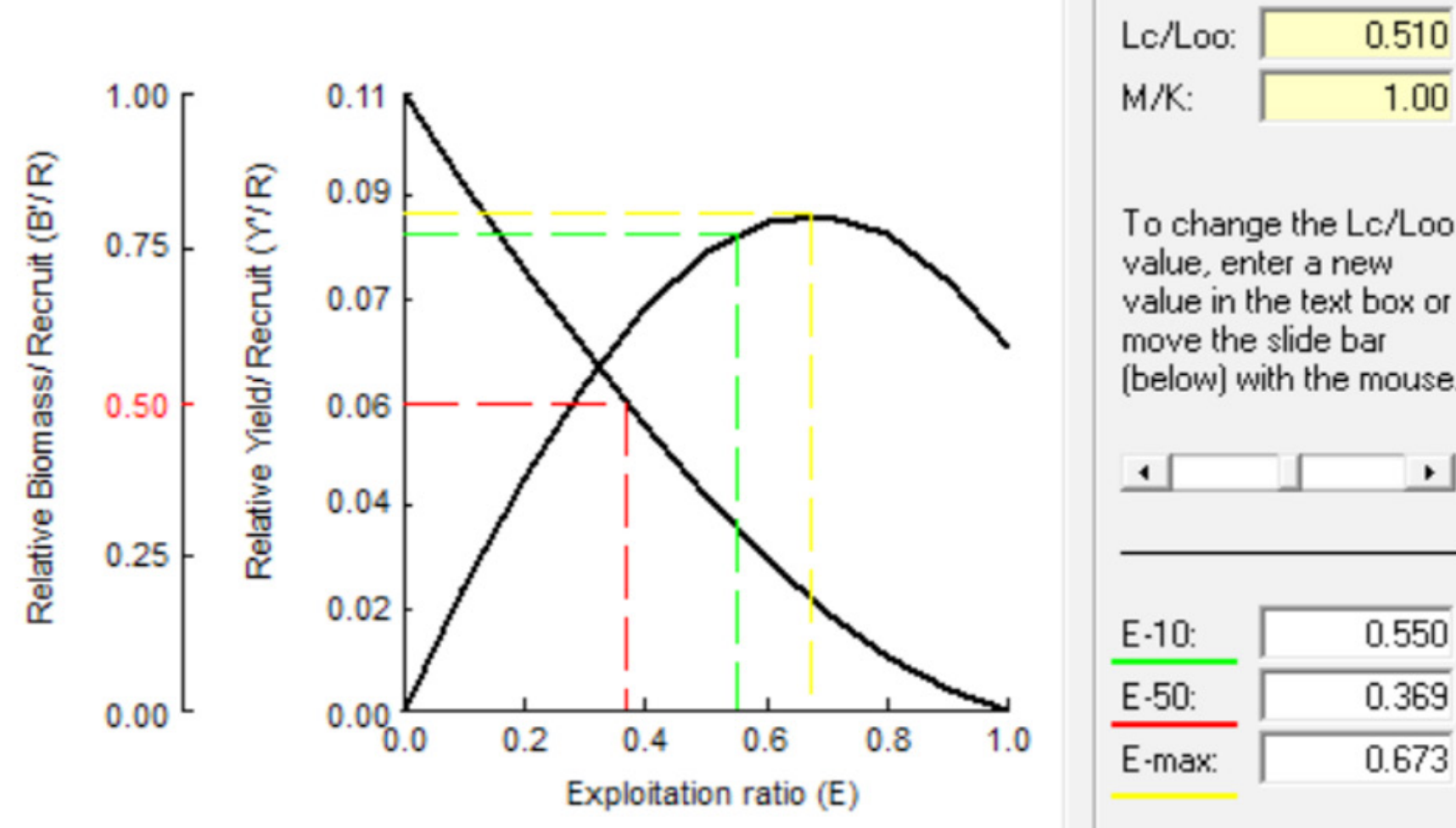

To change the Lc/Loo value, enter a new value in the text box or move the slide bar [below] with the mouse.

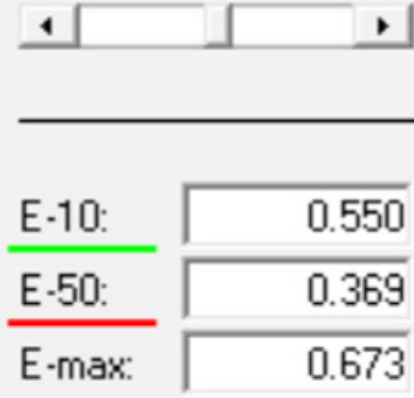

Figure 8. Biomass per recruit relative potency. It shows a certain phase relevant to the current catch result. 
that, the adaptability to current speed and oxygen are also relevant (Halswell et al., 2018).

The adaptive management strategy of the lobster population from the determined Total Allowable Catch (TAC) is to consider growth speed and biomass accumulating ability as a basis to determine TAC (Buglass et al., 2018). To ensure an increase in lobster biomass, it is necessary to monitor the catch closing program effectivity. According to Montez et al., (2012) in West Australia, the closed area does not guarantee an abundance, as natural predator persists and may also increase.

Jesus edwardsii lobster shows faster growth in shallow water than in deep water. Not only water movement and oxygen availability, food availability also caused a high amount of lobster larvae Bumbang Bay (Chandrapavan et al., 2010).

There exist five dominant lobster variants caught in Bumbang waters by fishermen, or in total there is $71 \%$ of the main variant found in Bumbang, meaning it classifies as the prime commodity in Bumbang and Lombok. Caught lobsters are usually juvenile lobsters with a length of no more than $10 \mathrm{~cm}$ and weigh less than 250 grams. Meanwhile, mature lobsters caught with size above Lc are 6-7\% of all population (of caught lobsters). This means the juvenile lobster population dominates. Lobster has a slow growth rate, high fecundity, and maximum breeding frequency estimate every mature lobster is twice a year. Therefore, there needs to be a great timing in lobster utilization, With high exploitation rate ( 0.6 per year), rapidly decreasing yield per recruit level, as well as biomass per recruit.

\section{Conclusion}

The higher the ratios of lobster catch size against the maximum allowed catch length, the higher the exploitation rate and lower the recruitment potency. Meaning there needs to be a utilization scenario on a certain time so that the lobster stock could be utilized in other ventures. The fishing activity should pay attention to critical phrases and the population of juvenile lobsters. To further increase the benefit, lobster seed utilization for aquaculture should be taken into account. There needs to be monitoring towards various competitor biota and predators, especially in larvae or juvenile stadiums of the lobster population.

\section{Acknowledgment}

On this occasion, the author would like to express gratitude to the research and technology ministry and the university for the financial support given through the scheme MP3EI, and also to all members supporting this research.

\section{Author's Contributions}

All authors discussed the results and contributed to from the start to final manuscript; Yon: Conduct research on population and export population biology teams, Zul: The research team coordinator and coordinate the team and are responsible for the social ecology system material, $\mathrm{Su}$ : As a research team for the fishing gear / lobster, Ben: As a lobster economic valuation research team, Fran: Survey Team that carries out field data collection, Sef: Survey Team that carries out field data collection, Rif: Survey Team that carries out field data collection

\section{Conflict of Interest}

The authors declare that they have no competing interests

\section{Funding Information}

This research is part of the MP3EI research program of the Ministry of Technology Research and Higher Education with No Contract No: 011 / SP2H / LT / DRPM / VIII / 2017.

\section{References}

Alborés, I., Soler, C. G., \& Fernandes, L. (2019). Reproductive biology of the slipper lobster Scyllarus arctus in Galicia (NW Spain): Implications for fisheries management. Fisheries Research, 212 : 1-11. doi.org/10.1016/j.fishres.2018.12.001.

Bevacqua, D., Melià, P., Follesa, M. C., De Leo, G. A., Gatto, M., \& Cau, A. (2010). Body growth and mortality of the spiny lobster Palinurus elephas within and outside a small marine protected area. Fisheries Research, 106 (3): 543-549. doi:10.1016/j.fishres.2010.10.008.

Blamey, L. K., de Lecea, A. M., Jones, L. D.S., \& Branch, G. M. (2018) Diet of the Spiny Lobster Jasus paulensis from the Tristan da Cunha Archipelagi: Comparison between Island, Depth and Lobster Sizes. Estuarine, Coastal and Shelf Science, 219: 262-272. doi.org/10.1016/j.ecss.2019.02.021.

Bris, A. L., Pershing, A. J., Gaudette, J., Pugh, T. L., \& Reardon, K. M. (2016). Multi-scale quantification of the-effects of temperature on size at maturity in the Americould lobster (Homarus 
americouldus). Fisheries Research, 186 (1): 397406. doi.org/10.1016/j.fishres.2016.09.008.

Buglass S, Reyes, H., Ramirez-González, J., Eddy, T. D., Salinas-de-León, P., \& Jarrin, J. M. (2018). Evaluating the effectiveness of coastal no-take zones of the Galapagos Marine Reserve for the red spiny lobster, Panulirus penicillatus. Marine Policy, 88: 204-212. doi.org/10.1016/j.marpol.2017.11.028.

Caputi, N., de Lestang, S., How, J., Trinnie, F., \& Fletcher, W. (2018). Ecosystem-based fisheries management (or 'triple bottom line') assessments of the western rock lobster resource: Is there an optimal target for fishing?. Marine Policy, 94: 264-274. doi.org/10.1016/j.marpol.2018.05.015.

Chandrapavan, A., Gardner, C., \& Green, B.S. (2010). Growth rate of adult rock lobsters Jasus edwardsii increased through translocation. Fisheries Research, 105: 244-247. doi:10.1016/j. fishres.2010.03.014.

Clark, A.S., Jury, S. H., Goldstein, J. S., Langley, T. G., \& Watson III, W. H. (2015). A comparison of Americould lobster size structure and abundance using standard and ventless traps. Fisheries Research, 167: 243-251. doi.org/10.1016/j. fishres.2015.02.016.

Driscoll, J., Boyd, C. \& Tyedmers, P. (2010) Life cycle assessment of the Maine and southwest Nova Scotia lobster industries. Fisheries Research, 172: 385-400.

http://dx.doi.org/10.1016/j.fishres.2015.08.007.

Froese, R. (2006). Cube law, condition faktor and weight length relationships: history, meta-analysis and recommendations. Journal of Applied Ichthyology, 22 (4): 241-253.

Goldstein, J.S., Morrissey, E. M., Moretti, E. D., \& Watson III, W. H. (2017). A comparison Of the distribution and abundance of European green crabs and Americould Lobsters in the Great Bay Estuary, New Hampshire, USA. Fisheries Research, 189: 10-17. doi.org/10.1016/j. fishres.2017.01.002.

Gardner, C., Hartmann, K., Punt, A. E., Jennings, S., \& Green, B. (2015). Bio-economics of commercial scale translocation of southern rock lobster. Fisheries Research, 162: 29-36. doi.org/10.1016/j. fishres.2014.09.015.

Harrington, A. M., Tudor, M. S., Reese, H. R., Bouchard, D. A., \& Hamlin, H. J. (2018). Effects of temperature on larval Americould lobster
(Homarus americouldus): Is there a trade-off between growth rate and developmental stability?. Ecological Indicators, 96 (1): 404-411. doi. org/10.1016/j.ecolind.2018.09.022.

Halswell. P., Daniels, C. L., \& Johanning, L. (2018). Framework for evaluating external and internal parameters associated with Sea Based Container Culture (SBCC): Towards understanding rearing success in European lobsters (Homarus gammarus). Aquacultural Engineering, 83: 109-119. doi.org/10.1016/j.aquaeng.2018.09.005.

Jenning, S., Kaiser, M. J., \& Reynolds, J. D. (2001) Marine fishery ecology. Blackwell Sciences. Oxford-US.

Manik, N. (2009). Hubungan Panjang-berat dan Faktor Kondisi Ikan Layang (Decapterus russelli) di Perairan Sekitar Bay Likupang, Sulawesi Utara. Oseanologi dan Limnologi di Indonesia, 5(1): 65-74

Partelow, S., \& Boda, C. (2015) A modified diagnostic social-ecological system framework for lobster fisheries: Case implementation and sustainability assessment in Southern California. Ocean \& Coastal Management, 114: 204-217. doi. org/10.1016/j.ocecoaman.2015.06.022.

Klaer, N., Wayte, S. E., \& Fay, G. (2012). An evaluation of the performance of a harvest Strategy an average-length-based assessment method that uses. Fisheries Research, 134- 136: 42- 51. doi. org/10.1016/ j.fishres.2012.08.010.

Priyambodo, B., Jones, C. M., \& Sammut, J. (2016). Improved collector design for the capture of tropical spiny lobsters, Panulirus homarus and $P$, ornatus (Decapoda: Palinuridae), pueruli in Lombok, Indonesia, Aquaculture, 479: 321-332. doi: 10.1016/j.aquaculture.2017.05.033.

Saputra, S. W. (2008). Distribusi Ruaya Udang Jari (Metapenaeus elegans de Man 1907) di Laguna Segara Anakan Cilacap Jawa Tengah. Jurnal Saintek Perikanan, 3 (2): 1-8.

Syafrizal, Jones, C. M., Purnama, I. G., \& Utomo, N. B. P. (2018). Effect of feeding frequency on survival and growth of juvenile spiny lobster Panulirus versicolor in Indonesia, AACL Bioflux, 11 (5): 1427-1434.

Tarkan, A. S., Gaygusuz, Ö., Acipinar, H., Gürsoy, C., \& Özulug, M (2006). Length-weight relationship of fishes from the Marmara region (NW-Turkey), Journal of Applied Ichthyology 22(4): 271-273. doi.org/10.1111/j.1439-0426.2006.00711.x. 
JIPK. Volume 11 No 2. November 2019 / Lobster Population Parameter in Bumbang Bay, Central Lombok......

Walpole, R. E. (1993). Pengantar Statistika. Jakarta: PT Gramedia Pustaka Utama.

Zargar, U. R., Yousuf, A. R., Mushtaq, B. \& Jan, D. (2012). Length-Weight Relationship of the Crucian carp, Carassius carassius in Relation to Water Quality, Sex and Season in Some Lentic Water Bodies of Kashmir Himalayas. Turkish Journal of Fisheries and Aquatic Sciences, 12: 685-691. 